\section{Aldersforskjeller i forebygging av kardiovaskulær sykdom}

\author{
I en britisk studie kunne man ikke \\ påvise kjønnsforskjeller i primær- \\ forbyggende tiltak mot kardiovas- \\ kulær sykdom.
}

Forskning har vist at det er alders- og kjønnsulikheter i sekundærforebygging av kardiovaskulær sykdom. Særlig gjelder dette kolesterolsenkende behandling. Engelske forskere har nå undersøkt om det også er slike forskjeller for primærforebyggende tiltak (1).

Journalopplysninger for 41250 personer over 40 år ble analysert. $89 \%$ hadde ikke kardiovaskulær sykdom og kunne derfor anses som mulig målgruppe for primærforebyggende behandling. Andelen av disse som fikk blodtrykkssenkende medikamenter økte fra 5\% i aldersgruppen 40-44 år til 57\% i gruppen $\geq 85$ år. Statinbruk økte fra $3 \%$ (40-44 år) til 29\% (70-74 år), men avtok i aldersgruppen $>74$ år. Det var ingen konsistente kjønnsforskjeller i forskrivningstrender, men totalt sett brukte flere kvinner antihypertensive legemidler og flere menn statiner.

- Studien viser alders- og kjønnsspesifikk prevalens av primærforebyggende medika-

Tidsskriftet

\section{VERDENS HELSE}

\section{Sinktilskudd i brød}

\section{Inntak av brød med sinktilskudd kan øke serumnivåene av sink og jern hos personer med sinkmangel.}

Sinkmangel er en av de vanligste kostholdrelaterte mangeltilstander $\mathrm{i} u$-land og er assosiert med vekstforstyrrelse, svekket immunforsvar, misdannelser, nevrofysiologiske funksjonsforstyrrelser, nattblindhet og svekket spermatogenese. I en nylig gjennomført studie i Iran har man evaluert hvilken effekt sinktilsetning i brød har på serumnivåer av sink og jern (1).

80 kvinner i alderen 19-49 år, ansatte eller studenter ved universitet i Isafahan i Iran, ble inkludert i studien. De hadde alle et sinknivå i serum på under $70 \mu \mathrm{g} / 100 \mathrm{ml}$, men var friske og uten klinisk tegn på mangeltilstand. I den dobbeltblinde studien ble de randomisert til enten vanlig brød, brød med lavt tilskudd av sinksulfat (50 mg Zn/kg mel) eller brød med høyt tilskudd (100 mg Zn/kg mel). Serumnivåer av sink og jern ble målt før og etter studieperioden på en måned.

Det var en statistisk signifikant økning $i$ serumnivåene av sink og jern i begge sink- mentbruk i engelsk allmennpraksis, sier forsker Hálfdán Pétursson ved Institutt for samfunnsmedisin, Norges teknisk-naturvitenskapelige universitet. - Forfatternes konklusjon er at statiner brukes for lite til primærforebygging for folk over 74 år, men de påpeker manglende gode studier når det gjelder dem over 80 år. Studiens svakhet er at man ikke vet hvor stor andel statinbrukere som er $\mathrm{i}$ høyrisikogruppen eller hvor stor andel «høyrisikanter» der er som bruker statiner. Polyfarmasi, komorbiditet og andre faktorer gjør at man kan ikke ta for gitt at statinbruk blant de eldste skulle anbefales, sier han.

- Det mest interessante funnet er at det var nesten ingen kjønnsforskjell i forebyggende medikamentbruk selv om vi vet at menn har betydelig høyere risiko enn kvinner på samme alder, sier Pétursson.

\section{Trine B. Haugen}

trine.b.haugen@hioa.no

\section{Litteratur \\ 1. Sheppard JP, Singh S, Fletcher K et al. Impact of age and sex on primary preventive treatment for cardiovascular disease in the West Midlands, UK: cross sectional study. BMJ 2012; 345: e4535.}

\section{Muskler som endokrint organ}

\author{
Fysisk aktivitet motvirker fedme \\ og insulinresistens. Nå foreligger \\ en mulig forklaringsmekanisme.
}

Under aktivitet utskiller skjelettmuskler myokiner. Nå er et nytt myokin - irisin identifisert (1). Det finnes i økt konsentrasjon $\mathrm{i}$ blodet både hos mus og hos mennesker etter fysisk trening og gjør hvitt fettvev «brunt-i-hvitt». Brune fettceller er mitokondrierike og kobler ut ATP-danning, slik at energi frigjøres som varme.

Man har visst at en transkripsjonskoaktivator, PGC-1 $\alpha$, er viktig i glukose-, lipidog energihomøostasen. PGC- $1 \alpha$ induseres i muskelceller av fysisk aktivitet og øker mengden av et membranprotein, FNDC5. Den ekstracellulære delen av dette proteinet kan spaltes av og blir til irisin.

Irisin aktiverte et bredt «brunt fettvev»genetisk program, oksygenforbruk og varmedanning hos hvite musefettceller in vitro og in vivo. Transgene fete mus med indusert overekspresjon av FNDC5 fikk lett nedsatt kroppsvekt, senket insulinnivå og litt bedret glukosetoleranse.

Det kan virke paradoksalt at økt energiforbruk i muskelvev skulle stimulere til økt energiforbruk også i fettvev, men dette kunne kanskje utnyttes medikamentelt?

- Irisin kan være et viktig bindeledd mellom fysisk aktivitet og metabolsk kontroll, inkludert vektkontroll, sier professor Hege Thoresen, Avdeling for farmakologi, Institutt for klinisk medisin, Universitetet i Oslo.

- Dette arbeidet bekrefter at fysisk aktivitet gjør mer enn bare å øke forbrenningen i musklene. Irisin føyer seg inn i rekken av myokiner som frigjøres ved aktivitet. Det kan bidra til forståelsen av hvordan energimetabolisme og kroppsvekt reguleres, og kanskje også til utvikling av legemidler mot sykdommer som vi vet bedres ved fysisk aktivitet - spesielt der fysisk aktivitet er vanskelig å gjennomføre. Artikkelen illustrerer også hvor komplekst arbeidende muskelvev og andre vev i kroppen kommuniserer. Å trene vil derfor alltid være bedre medisin enn å påvirke én enkelt mekanisme farmakologisk, sier Thoresen.

\section{Haakon B. Benestad}

h.b.benestad@medisin.uio.no

Universitetet i Oslo

\footnotetext{
Litteratur

1. Badii A, Nekouei N, Fazilati M et al. Effect of consuming zinc-fortified bread on serum zinc and iron status of zinc-deficient women: a double blind randomized clinical trial. Int J Prev Med 2012; 3 (suppl 1): S124-30.
}

Boström P. Wu J, Jedrychowski MP et al. A PGC1 $\alpha$-dependent myokine that drives brown-fat-like development of white fat and thermogenesis. Nature 2012; 481: 463-8. 